\title{
Qualitative-Feed-Restricted Heavy Swine: Meat Quality and Morpho-Histochemical Characteristics of Muscle Fibers
}

\author{
Alessandro Luís Fraga "in memoriam", Maria Cristina Thomaz", Rodolfo Nascimento \\ Kronka, Fábio Enrique Lemos Budiño, Rizal Alcides Robles Huaynate, Antônio João \\ Scandolera, Urbano dos Santos Ruiz and Flora Helena de Freitas D'Angelis \\ Faculdade de Ciências Agrárias e Veterinárias; Universidade Estadual Paulista; Rodovia Paulo Donato Castelane, \\ s/n; 14884-900; Jaboticabal - SP - Brasil
}

\begin{abstract}
To evaluate the effect of different levels of qualitative feed restriction (0, 5, 10, 15 and 20\%) on pork quality and muscle morpho-histochemical characteristics, 60 castrated male swines were used. Ten animals were slaughtered at $89 \mathrm{~kg} \mathrm{BW}$. Other 50 pigs were fed experimental diets and slaughtered at $128 \mathrm{~kg} \mathrm{BW}$. Qualitative restriction increased $\mathrm{pH}_{45}$, and water holding capacity, and reduced the redness, yellowness and cholesterol concentrations of Longissimus lumborum. Quadratic tendency for oleic acid contents of loin and fiber cross-section area of Multifidus dorsi $(P=0.08)$ were observed, with maximum point at 11-12\% of restriction. No effect $(P>0.1)$ on percentage of $M$. dorsi fibers SO, FG and FOG was found. The meat from 128-kg-BW pig showed numerically higher values for colorness, water losses, and lipid content and lower shear force than 89-kg-BW pigs. Qualitative feed restriction for finishing swines neither affected negatively pork quality nor modified the muscle fiber profile.
\end{abstract}

Key words: Color, fatty acid profile, muscle fiber, nutritional value, tenderness

\section{INTRODUCTION}

Slaughter weight of swine has been increasing in last years, including Brazil. System of typification offers the best value for heavyweight carcasses, since animals do not deposit excessive fat (Sainz and Araújo, 2001). However, heavier swines typically present fattier carcasses and to control fat deposition, the reduction of energy intake can be used (Ellis et al., 1996). Qualitative feed restriction is based on the inclusion of low density ingredient to diets providing less intake of energy (Ramonet et al., 1999).

However, variations on either quantity or type of diets may interfere on meat quality. Pork quality involves many characteristics, such as colour, flavor, juiciness, tenderness, cooking losses, nutritional levels, etc. Intramuscular fat content is influenced by energy and composition of diet (Fernandes et al., 1999; Petigrew and Esnaola, 2001) and shows influence in pork flavor, juiciness and tenderness (Brewer et al., 2001). Feed restriction and diet composition changes intramuscular fat content, fatty acid profile and sensorial characteristics of pork meat (Cameron et al., 2000). According to Ellis et al. (1996), feed restriction reduces pork tenderness.

Characteristics of muscle fiber, such as kind of

* Author for correspondence: thomaz@fcav.unesp.br 
metabolism and area (size) are related with colour and water holding capacity of pork. Fibers with glycolitycal metabolism are related with the development of PSE - pale, soft and exsudative condition in meat (Klont et al., 1998). On the other hand, effects of feed restriction for growing pigs on morpho-histochemistry of muscle fiber have not been defined yet, and several different results have been observed (Lefaucher and Gerrard, 1998).

The aim of this study was to evaluate the qualitative meat characteristics as well as morphohistochemical patterns of muscle fibers from pigs subjected to qualitative feed restriction from 89 to $128 \mathrm{~kg} \mathrm{BW}$.

\section{MATERIALS AND METHODS}

\section{Housing animals, and experimental diets}

Sixty castrated males purchased from a commercial operation (crossbred swines selected for lean meat production) were allotted in individual pens $\left(2.55 \mathrm{~m}^{2}\right)$ equipped with semiautomatic feeders and communicating vessel drinkers. After two weeks adjustment period, animals reached $89.1 \pm 4.2 \mathrm{~kg} \mathrm{BW}$, next to slaughter weight practiced in Brazil and a group of ten swines with weight around the average $(89.3 \pm$ $2.2 \mathrm{~kg}$ ) were slaughtered (a reference weight group). Other 50 pigs were fed experimental diets formulated to supply different levels of qualitative restriction (Table 1).

Table 1 - Feed composition of experimental diets.

\begin{tabular}{|c|c|c|c|c|c|}
\hline \multirow{2}{*}{ Feedstuffs, \% } & \multicolumn{5}{|c|}{ Qualitative feed restriction, $\%$} \\
\hline & $\mathbf{0}$ & 5 & 10 & 15 & 20 \\
\hline Corn & 83.99 & 78.67 & 73.36 & 68.04 & 62.73 \\
\hline Soybean meal & 14.34 & 14.77 & 15.20 & 15.63 & 16.06 \\
\hline Rice hull ${ }^{(1)}$ & - & 4.94 & 9.83 & 14.72 & 19.60 \\
\hline Limestone & 0.767 & 0.745 & 0.723 & 0.702 & 0.680 \\
\hline Dicalcium phosphate & 0.300 & 0.319 & 0.337 & 0.356 & 0.375 \\
\hline Salt & 0.250 & 0.250 & 0.250 & 0.250 & 0.250 \\
\hline Mineral premix ${ }^{(2)}$ & 0.150 & 0.150 & 0.150 & 0.150 & 0.150 \\
\hline Vitamin premix ${ }^{(2)}$ & 0.150 & 0.150 & 0.150 & 0.150 & 0.150 \\
\hline \multicolumn{6}{|l|}{ Calculated composition ${ }^{(3)}$} \\
\hline Digestible Energy, $\mathrm{kcal} / \mathrm{kg}$ & 3407 & 3240 & 3060 & 2890 & 2720 \\
\hline Crude protein, $\%$ & 13.7 & 13.6 & 13.5 & 13.4 & 13.2 \\
\hline Digestible lysine. $\%$ & 0.52 & 0.52 & 0.52 & 0.52 & 0.52 \\
\hline Calcium, $\%$ & 0.44 & 0.44 & 0.44 & 0.44 & 0.44 \\
\hline Non-phytate phosphorus, \% & 0.15 & 0.15 & 0.15 & 0.15 & 0.15 \\
\hline Crude fiber, $\%$ & 2.5 & 4.3 & 6.2 & 8.0 & 9.9 \\
\hline
\end{tabular}

${ }^{1}$ Finely grinded carrier of vitamin premix without nutritive values; energy, digestible Lys and/or non-phytate phosphorus according to EMBRAPA (1991);

${ }^{2}$ Supplied per kg of diet: $\mathrm{Fe}-60,0 \mathrm{mg} ; \mathrm{Cu}-52.5 \mathrm{mg} ; \mathrm{Mn}-30.0 \mathrm{mg} ; \mathrm{Zn}-60 \mathrm{mg}$; Co - $0.54 \mathrm{mg}$; I - $1.26 \mathrm{mg}$; $\mathrm{Se}-0.18 \mathrm{mg}$; Vitamin A - $3.750 \mathrm{UI} ; \mathrm{D}_{3}-750 \mathrm{UI}$; E - $11.25 \mathrm{mg}$; $\mathrm{K}_{3}-1.5 \mathrm{mg} ; \mathrm{B}_{2}-2.7 \mathrm{mg}$; $\mathrm{B}_{12}-10.5 \mu \mathrm{g}$; Calcium pantotenate $-4.5 \mathrm{mg}$; Niacin - $15 \mathrm{mg}$; Biotin - $0.075 \mathrm{mg}$; Choline - $75 \mathrm{mg}$; Antioxidant - $37.5 \mathrm{mg}$;

${ }^{3}$ Nutritional compositions according to Rostagno et al (2000). Nutritional levels recommended by NRC (1998) software for castrated male pig with deposition of $375 \mathrm{~g} /$ day of lean tissue, and $107.5 \mathrm{~kg} \mathrm{BW}(90-125 \mathrm{~kg})$.

During adjustment period, the animals were fed corn-soy diet with $3400 \mathrm{kcal} \mathrm{DE} / \mathrm{kg}, 0.63,0.47$, and $0.17 \%$ of digestible lysine, calcium and available phosphorus, respectively. 


\section{Management and slaughter of animals}

Animals had ad lib access to feed and water throughout the adjustment and experimental periods. Slaughter of the heavy swines occurred weekly when reaching approximately $128 \mathrm{~kg} \mathrm{BW}$, composing a total of five groups apart from that first group slaughtered with $89 \mathrm{~kg} \mathrm{BW}$ (reference weight).

After $12 \mathrm{~h}$ of feed fast period, animals were loaded in a wooden body truck. The interior divisions were openned or closed, according to the number of animals, in order to minimize the discrepancy in the density of the weekly groups along the transportation to the slaughter plant. Time of loading, transportation, and unshipping took about 2h. After 2-h rest, swines were slaughtered. Carcass was obtained after stunning with electric charge, bleeding, scalding, scraping, and evisceration. Every slaughtering procedure was done using the same method.

\section{Collection and preparation of muscles samples for histological analysis}

With the aid of a lancet, cubic samples of Multifidus dorsi muscle from lumbar region were colleted at the slaughter line. This muscle has respectively origin and insertion on lateral and spinous processes of vertebras thus, $M$. dorsi is disposed along the vertebral column, deeper than Longissimus muscle (Jones et al. 2006). After longitudinal opening of carcasses, $M$. dorsi is exposed between the lumbar vertebrae bodies and the backfat, being possible to access to this muscle without transversal cuts of carcass.

Samples were cut in $0.5 \times 0.5 \times 0.8 \mathrm{~cm}$ pieces, dried in neutral power talcum for cryo protection (Fonseca et al., 2003), submerged in liquid nitrogen, and disposed in labeled chilled eppendorf. Samples were transported in liquid nitrogen bottle and stored in a freezer at $-70^{\circ} \mathrm{C}$. Afterwards, $10-\mu \mathrm{m}$-thick semi-serial cross slices were obtained using cryostat apparatus at $-20^{\circ} \mathrm{C}$. Each piece was disposed in identified slide which was maintained in a freezer at $-70^{\circ} \mathrm{C}$ until subsequent staining could be performed within a week.

The slides were histochemically processed for evaluation of myosin twitch property and type of metabolism of the muscle fiber. The slides were dried at room temperature $\left(22\right.$ to $\left.25^{\circ} \mathrm{C}\right)$ for $40 \mathrm{~min}$. For contraction capacity of muscle fiber, ATPase myofiber (m-ATPase) assay was employed. The pieces were fixed in 5\% buffered formalin; $0.34 \mathrm{M}$ sucrose, $0.13 \mathrm{M}$ sodium cacodylate, and $0.17 \mathrm{M}$ calcium chloride, adjusted to $\mathrm{pH} 7.4$ with potassium hydroxide for $6 \mathrm{~min}$ at room temperature, washed in $21 \mathrm{mM}$ TRIS-base buffer; $3.4 \mathrm{mM}$ calcium chloride at $\mathrm{pH} 7.8$ adjusted with chloride acid (Guth and Samaha, 1970). Thus, samples were pre-incubated in $52 \mathrm{nM}$ potassium acetate solution containing $17.7 \mathrm{mM}$ calcium chloride adjusted to $\mathrm{pH} 4.5$ with glacial acetic acid for $6 \mathrm{~min}$ at room temperature (Ogilvie and Feeback, 1990), followed by new washing with TRIS-base buffer. Basic incubation was done in $2.5 \mathrm{mM}$ ATP solution, $40 \mathrm{mM}$ glicine, and $20 \mathrm{mM}$ calcium chloride adjusted to $\mathrm{pH} 10.5$ using potassium hydroxide for $5 \mathrm{~min}$ at $37^{\circ} \mathrm{C}$ (Ennion et al., 1995). Slides were washed in $1 \%$ calcium chloride solution during $3 \mathrm{~min}$, stained with $1 \%$ toluidine blue for $10 \mathrm{sec}$, dehydrated in graded ethanol solutions, diaphanized in xilol, and then mounted in entelan (Ogilvie and Feeback, 1990). For evaluation of oxidative-glicolytic cellular metabolism, NADH-TR method (Dubowitz and Brooke, 1973) was applied. After drying, pieces were incubated at $37^{\circ} \mathrm{C}$ for $40 \mathrm{~min}$ in TRIS $0.2 \mathrm{M}$ buffer solutions at $\mathrm{pH} 7.4$ containing $8 \mathrm{mg}$ of reduced NADH and $10 \mathrm{mg}$ of NitroBlueTetrazólio / $10 \mathrm{~mL}$. After washing in distilled water, slides were fixed in buffered formalin at $5 \%$, rewashed in distilled water, and finally mounted in entelan.

Muscle fibers were classified according to Peter et al. (1972), considering contraction capacity (slow or fast-twicth) and metabolism (oxidative, glicolytic or both) as either SO, FG or FOG fibers. Histological images were obtained in CAMEDIA OLYMPUS 95-98ME ${ }^{\circledR}$ photo microscope, and measurements were done with the aid of image analyze software (IMAGE PRO PLUS CYBERNETIC $^{\circledR}$ ).

Cross sections areas of muscle fibers were measured in $\mu \mathrm{m}^{2}$, evaluating 25 units of each fiber type per sample. Frequency of fiber types calculated in relation to the total number of fibers present in each microscopic field was also determined. Four fields of $584957.1 \mu \mathrm{m}^{2}$ in area were examined using 20x magnification.

\section{Qualitative evaluation of meat}

Longissimus lumborum muscle was evaluated. The $\mathrm{pH}$ of the muscle was determined in hot carcass 45 min post mortem $\left(\mathrm{pH}_{45}\right)$ and in chilled carcass maintained in frozen chamber $\left(-2^{\circ} \mathrm{C}\right)$ for $24 \mathrm{~h}$ $\left(\mathrm{pH}_{24 \mathrm{~h}}\right)$, using pHMETER DIGITAL TEXTO $230^{\circledR}$. 
A 20-cm-thick chop of L. lumborum muscle, without adjacent fat was removed and physical analyzes of meat were done immediately.

$\mathrm{L}^{*}$ (lightness), $\mathrm{a}^{*}$ (redness), and $\mathrm{b}^{*}$ (yellowness) evaluations (MINOLTA ${ }^{\circledR}$ colorimeter) of meat samples $( \pm 2 \mathrm{~cm}$ tick) were taken at $40 \mathrm{~min}$ after air exposure for reaction of myoglobin with atmospheric oxygen (Shimokomaki, 2003).

Cuts were processed in oven to determine the cooking losses. Cylindrical fragments of cooked chops were tested in a TEXTURE ANALYZER TA$X T-125^{\circledR}$ apparatus for mensuration of shear force (Corte et al., 1979). Water holding capacity of raw meat was also determined in 2g-fragments involved in filter paper, and compressed under a 2kg weight (Hamm, 1986).

Chops of Longissimus were stored in a freezer ($20^{\circ} \mathrm{C}$ ) until subsequent chemical analysis was performed. Chloroform-methanol (2:1) extraction of fat by solubilization was done to determine the total fat content after drying the extract (Bligh and Dyer, 1959). Determination of cholesterol levels of the meat was taken by saponification of extract obtained by solubilization in chloroform-ethanol (2:1) solution, followed by colorimetric reading (Bragnolo and Rodriguez-Amaya, 2002).

Following the same procedure of fat extraction (Bligh and Dyer, 1959), concentrated extracts obtained in a rotoevaporator $\left(60^{\circ} \mathrm{C}\right)$ were utilized for fatty acid sterification (Bragnolo and Rodriguez-Amaya, 2002). Fatty acid profiles were analyzed through the injection of $1 \mu \mathrm{L}$ of the extract in gas chromatography equipment (SHIMATZU $G C-14 B^{\circledR}$ ), with initial and final column temperatures 100 and $220^{\circ} \mathrm{C}$, respectively, rising at $4^{\circ} \mathrm{C}$ per min. SIGMA ${ }^{\circledR}$ standard catalogue 189-9 was adopted as reference of fatty acid reading.

\section{Statistical analyses}

All obtained data were tested for normality of error distributions (Shapiro-Wilk's test at 5\%) and homogeneity of variance (Levene's test at 5\%) among the treatments before the analysis of variance that was processed by PROC GLM of SAS (1998) software, according to following model:

$\mathrm{Y}_{i j}=\mu+\mathrm{D}_{i}+\mathrm{Bl}_{j}+\mathrm{e}_{i j}$

Where:

$\mathrm{Y}_{i j}$ : Observed value for $i$ qualitative feed restriction level in $j$ block $\mu$ : General constant;

$\mathrm{D}_{i}$ : Effects of experimental diets, $i=1, \ldots, 5$;

$\mathrm{Bl}_{j}$ : Effects of $j$ block, $j=1, \ldots, 10$;

$\mathrm{e}_{\mathrm{ij}}$ : Associated error to $i$ qualitative restriction level in $j$ block.

For the analysis of meat quality results, day of slaughter was used in the model. For $\mathrm{pH}_{45}$ parameter, sequence in slaughter was performed as co-variable. Weight of slaughter was considered as co-variable in the statistical model. Also, Pearson's correlation test among physical characteristics and morpho-histochemistry results of L. lumborum and M. dorsi muscles were carried out, respectively.

\section{RESULTS AND DISCUSSION}

Four animals were removed from the experimental groups due to obit, testicles retention in abdominal cavity, leg problems, and others for culling. Five samples prepared for morpho-hystochemical analysis were discarded since no feasible microscope images were obtained. Fatty acid profile and frequency of SO fiber data did not show normal curves $(\mathrm{P}<0.05)$, being submitted to arc-sin transformations.

\section{Physical quality of meat}

The effect of qualitative restriction on pork characteristics are shown in Table 2. Even adopting rigorous standard procedure for preslaughtering, effects of the day were observed $(\mathrm{P}<0.01)$ since it was not possible to control all the variables, mainly those related to environment.

Qualitative feed restriction increased $(\mathrm{P}=0.085)$ $\mathrm{pH}_{45}$, and water holding capacity $(\mathrm{P}=0.04)$, and reduced $(\mathrm{P}<0.05) \mathrm{a}^{*}$ and $\mathrm{b}^{*}$ values of pork loin. The other characteristics did not respond to the qualitative restriction levels.

Reduction of meat $\mathrm{pH}$ after slaughter occurs as consequence of conversion of glycogen content of the muscle into lactic acid. Thus, the more glycogen the muscle contains at the time of slaughter, more fastly drop of $\mathrm{pH}$ occurs, lowering the $\mathrm{pH}_{45}$ (Warriss, 1995). Thus, the energetic restriction may decrease the reserve of muscular glycogen, slowing meat acidification and promoting higher $\mathrm{pH}_{45}$, as the levels of qualitative feed restriction increase. Lower values of $\mathrm{pH}_{45}$, are correlated to lower water holding capacity of the 
meat as consequence of modifications of the sarcoplasmatic proteins that occur after fast muscular acidification (Garrido et al., 1994).

$\mathrm{L}^{*}, \mathrm{a}^{*}$ and $\mathrm{b}^{*}$ values are related to meat color; higher values are indicative of higher lightness, redness and yellowness, respectively, of the meat (Warriss, 1995). High levels of qualitative feed restriction determined a decrease in colorness of the pork meat. To dilute the energy content, rice hulls replaced corn in the experimental diets composition, reducing their carotene content. As mentioned by Akiba et al. (2001), there was a linear relationship between concentration of carotene in the diet and color of broiler meat.

Pork characteristics of $89-\mathrm{kg}-\mathrm{BW}$ slaughtered swines are shown in Table 3 . The meat of heavy animals showed numerical higher values of $\mathrm{pH}_{24 \mathrm{~h}}$, $\mathrm{L}^{*}, \mathrm{a}^{*}, \mathrm{~b}^{*}$, and cooking losses; lower values of $\mathrm{pH}_{45}$, water holding capacity, and shear force.

Table 2 - Effect of qualitative feed restriction on meat quality of heavy swine.

\begin{tabular}{|c|c|c|c|c|c|c|}
\hline \multirow{2}{*}{ Characteristics } & \multicolumn{5}{|c|}{ Qualitative feed restriction, \% } & \multirow{2}{*}{$\mathbf{P}$} \\
\hline & $0(n=9)$ & $5(n=9)$ & $10(n=9)$ & $15(n=10)$ & $20(n=9)$ & \\
\hline $\mathrm{pH}_{45},{ }^{(1)}$ & $6.14 \pm 0.08$ & $6.19 \pm 0.08$ & $6.25 \pm 0.10$ & $6.30 \pm 0.09$ & $6.33 \pm 0.09$ & $\mathrm{~L}(0.085)$ \\
\hline $\mathrm{pH}_{24 \mathrm{~h}}$ & $5.54 \pm 0.02$ & $5.50 \pm 0.02$ & $5.59 \pm 0.03$ & $5.54 \pm 0.03$ & $5.56 \pm 0.03$ & NS \\
\hline $\mathrm{L}^{*}$ & $51.7 \pm 0.9$ & $51.8 \pm 0.8$ & $51.3 \pm 1.0$ & $59.7 \pm 0.9$ & $50.0 \pm 0.9$ & NS \\
\hline $\mathrm{a}^{*(2)}$ & $7.96 \pm 0.28$ & $7.88 \pm 0.27$ & $7.44 \pm 0.33$ & $7.42 \pm 0.31$ & $7.06 \pm 0.30$ & $\mathrm{~L}(0.02)$ \\
\hline$b^{*}(3)$ & $3.34 \pm 0.31$ & $3.67 \pm 0.28$ & $2.88 \pm 0.34$ & $2.75 \pm 0.32$ & $2.30 \pm 0.31$ & $\mathrm{~L}(<0.01)$ \\
\hline Water holding capacity, $\%{ }^{(4)}$ & $64.0 \pm 0.81$ & $64.8 \pm 0.78$ & $67.4 \pm 0.96$ & $66.2 \pm 0.90$ & $66.2 \pm 0.87$ & $\mathrm{~L}(0.04)$ \\
\hline Cooking losses, $\%$ & $34.7 \pm 0.9$ & $35.6 \pm 0.9$ & $34.6 \pm 1.1$ & $34.1 \pm 1.0$ & $34.7 \pm 1.0$ & NS \\
\hline Shear force, $\mathrm{kgf} / \mathrm{cm}^{2}$ & $2.69 \pm 0.11$ & $2.62 \pm 0.10$ & $2.99 \pm 0.13$ & $2.64 \pm 0.12$ & $2.87 \pm 0.12$ & NS \\
\hline $\begin{array}{l}\mathrm{pH}_{45^{\prime}}=6.14+0.0098 \mathrm{x}\left(\mathrm{R}^{2}=0.99\right) \\
\mathrm{a}^{*}=8.004-0.045 \mathrm{x}\left(\mathrm{R}^{2}=0.94\right) \\
\mathrm{b}^{*}=3.582-0.06 \mathrm{x}\left(\mathrm{R}^{2}=0.79\right) \\
\text { Water holding capacity }=64.85+0\end{array}$ & & & & & & \\
\hline
\end{tabular}

Table 3 - Average ( \pm s.e.m.) values of physical properties of meat from swines slaughtered at $89 \mathrm{~kg} \mathrm{BW}(n=10)$.

\begin{tabular}{|c|c|c|c|c|c|c|c|}
\hline $\mathrm{pH}_{45}$ & $\mathrm{pH}_{24 \mathrm{~h}}$ & $\mathrm{~L}^{*}$ & $\mathrm{a}^{*}$ & $\mathrm{~b}^{*}$ & $\mathrm{WHC}^{(1)}, \%$ & $\mathrm{CL}^{(1)}, \%$ & $\mathrm{SF}^{(1)}, \%$ \\
\hline $6.49 \pm 0.06$ & $5.44 \pm 0.02$ & $49.7 \pm 0,5$ & $6.98 \pm 0.20$ & $2.25 \pm 0.13$ & $69.9 \pm 0.7$ & $32.1 \pm 0,7$ & $3.05 \pm 0.13$ \\
\hline
\end{tabular}

(1) WHC - water holding capacity; CL - cooking losses; SF - shear force

According to Garrido et al. (1994), values of $\mathrm{pH}_{45}$. $<6.1$, and $\mathrm{L}^{*}>60$ are indicative of PSE meat with high water loss as result of sarcoplasmatic protein denaturation due to fast muscular acidification; $\mathrm{pH}_{24 \mathrm{~h}}>6.0$, and $\mathrm{L}^{*}<48$ are indicative of DFD carcass that shows high water holding, as consequence of the small reduction in the ultimate $\mathrm{pH}$ of the meat (Warriss, 1995; Fernandez et al., 1999). Thus, although all the tested carcasses showed $\mathrm{pH}$ values within normal range, $128-\mathrm{kg}$ BW slaughtered swines presented lower $\mathrm{pH}_{45}$ and higher water losses, characteristics closer to PSE conditions than animals slaughtered with $89 \mathrm{~kg}$ BW. However, slaughter of heavy animals occurred at average temperature of $15.9^{\circ} \mathrm{C}$ at the moment of departure, while $89-\mathrm{kg}-\mathrm{BW}$ swinbes were removed to slaughter plant at $11.1^{\circ} \mathrm{C}$. According to Guárdia et al. (2004), increased temperature was co-related to higher incidence of PSE pork meat, so that diverse environment conditions at the time of slaughter probably influenced the differences on meat quality here recorded.

Higher color intensity ( $a^{*}$ and $b^{*}$ values) observed for the carcasses of heavy animals could be attributed to carotenoids of corn. Swines were fed sorghum-based-diet at previous farm. Nevertheless, the particular effects of the BW could not be omitted, since Ellis et al. (1996) observed increase in muscle colour and Latorre et al. (2004) described higher redness and 
concentration of myoglobin in the meat as BW of swine increases.

Ellis et al. (1996), Cisneros et al. (1996) and Latorre et al. (2004) recorded respectively increase, numerically reduction and no alteration on shear force value of pork with higher slaughter weight. However, the reduction of tenderness scores with slaughter weight was more evident, although shear force value was an indicative of tenderness. This contradictory observation could be due the subjective indication of tenderness that might be influenced by juiciness (Warriss, 1995). This variable was influenced by water holding capacity which was reduced in heavier animals, as in this trial as recorded by Ellis et al. (1996) and Cisneros et al. (1996).

\section{Meat fat composition}

Table 4 shows fat composition of loin pork related to qualitative levels of feed restriction. Quadradic effect $(\mathrm{P}=0.08)$ was observed for oleic fatty acid $(18: \ln 9)$ showing calculated maximum point of $12.6 \%$ of qualitative restriction. Also linear reduction on cholesterol content of $(\mathrm{P}<0.05)$ loin in response to increased qualitative restriction levels was observed. Other analyzed traits did not respond $(\mathrm{P}>0.1)$ to experimental diets.

Table 4 - Effect of qualitative feed restriction on fat composition of heavy swine meat

\begin{tabular}{|c|c|c|c|c|c|c|}
\hline \multirow{2}{*}{ Fat composition } & \multicolumn{5}{|c|}{ Qualitative feed restriction, \% } & \multirow{2}{*}{$\mathbf{P}$} \\
\hline & $0(n=9)$ & $5(n=9)$ & $10(n=9)$ & $15(n=10)$ & $20(n=9)$ & \\
\hline \multicolumn{7}{|l|}{ Fatty acid, $\%$} \\
\hline $16: 0$ & $26.1 \pm 0.5$ & $26.3 \pm 0.5$ & $26.2 \pm 0.5$ & $25.7 \pm 0.5$ & $26.4 \pm 0.5$ & NS \\
\hline $18: 0$ & $10.5 \pm 0.6$ & $10.2 \pm 0.6$ & $11.3 \pm 0.6$ & $10.9 \pm 0.6$ & $11.0 \pm 0.6$ & NS \\
\hline $18: \ln 9^{(1)}$ & $36.6 \pm 1.3$ & $36.1 \pm 1.3$ & $39.9 \pm 1.3$ & $40.3 \pm 1.3$ & $37.5 \pm 1.3$ & $\mathrm{Q}(0.08)$ \\
\hline $18: 2 \mathrm{n} 6$ & $13.2 \pm 1.5$ & $13.3 \pm 1.5$ & $10.1 \pm 1.5$ & $9.7 \pm 1.4$ & $11.7 \pm 1.5$ & NS \\
\hline Saturated & $38.2 \pm 1.0$ & $38.1 \pm 1.0$ & $39.2 \pm 1.0$ & $38.3 \pm 1.0$ & $39.0 \pm 1.0$ & NS \\
\hline Monounsaturated & $44.9 \pm 1.4$ & $44.3 \pm 1.4$ & $47.8 \pm 1.4$ & $49.1 \pm 1.3$ & $45.7 \pm 1.4$ & NS \\
\hline Polyunsaturated & $16.9 \pm 2.0$ & $17.6 \pm 2.0$ & $13.0 \pm 2.0$ & $12.6 \pm 1.9$ & $15.3 \pm 2.0$ & NS \\
\hline Unsaturated/ Saturated & $1.65 \pm 0.07$ & $1.64 \pm 0.07$ & $1.57 \pm 0.07$ & $1.62 \pm 0.07$ & $1.59 \pm 0.07$ & NS \\
\hline Total lipid, \% & $3.33 \pm 0.33$ & $3.36 \pm 0.33$ & $3.20 \pm 0.33$ & $3.65 \pm 0.32$ & $2.86 \pm 0.33$ & NS \\
\hline Cholesterol, mg/100g ${ }^{(2)}$ & $31.1 \pm 1.4$ & $31.4 \pm 1.5$ & $30.8 \pm 1.4$ & $24.3 \pm 1.4$ & $24.9 \pm 1.4$ & $\mathrm{~L}(0.02)$ \\
\hline
\end{tabular}

Acording to Kay (1982), the presence of cellulose and lignin in diet increase the biliar salts excretion, what would represent a way to increase the catabolism of cholesterol. Cecal fiber fermentation can produce components that contribute to reduce cholesterol syntesis (Delaney et al., 2003). However, animals do not show serum cholesterol reduction (not published data) with the increase of fiber in the diet. Nutritional effect in reduction of pork cholesterol content was observed by Souza and Silva (2006). Thus, although the serum concentrate was kept constant, less cholesterol was deposited in muscle, according to the energy content of diet was reduced by fiber inclusion.
Level of unsaturated fatty acid is inversely related to the content of meat intramuscular fat (Affentranger et al., 1996; Cameron et al., 2000). Data reported by Affentranger et al. (1996) indicated that unsaturated fatty acid levels increased when intramuscular fat content was reduced by feed restriction. In the present work, lipid content was not affected by the energy intake. However, oleic acid showed response to the diets. Quantitative restriction decreased C18 fatty acids (including oleic acid) percentage in pork loin, without changing in other fatty acids (Cameron et al., 2000). In this trial, treatments differed in energy, fat (corn was replaced by rice hulls) and 
fiber content, what could promote the quadratic comportament of the oleic acid level in pork loin.

Beyond lower quantity of cholesterol content, the presence of monoinsusatured fatty acids in diets of human nutrition is recommended (Garnier et al., 2003). Thus, qualitative feed restriction levels improved the lipid composition of loin on the point of human nutrition.

Total lipid content is related with meat intramuscular fat and is considered important factor in the determination of sensorial characteristics (Fernandez et al., 1999). The absence of diet effects on lipid content shows the viability of the use of qualitative feed restriction for heavy pigs. However, the numerical lower value observed for $20 \%$ restriction level (2.86\%) indicated that further increase in the level of restriction could reduce the loin lipid content, although this value was within the minimum 2 to $3 \%$ required to confer flavor and succulence to pork meat (Warris, 1995).

Lipid composition of meat from $89-\mathrm{kg}-\mathrm{BW}$ slaughter swines is shown in Table 5. The meat from heavy pigs showed numerical greater levels of oleic acid, and monounsatured and saturated fatty acids, and lower levels of polyunsaturated fatty acids. The level of cholesterol was similar to the heavy pigs, but the value is numerically different for 15 and $20 \%$-qualitative restriction diets.

Table 5 - Average ( \pm s.e.m.) values of lipid composition of meat from swines slaughtered at $89 \mathrm{~kg} \mathrm{BW}(n=10)$.

\begin{tabular}{|c|c|c|c|c|c|}
\hline \multicolumn{4}{|c|}{ Fatty acid, \% } & \multirow{2}{*}{ Total lipid, \% } & \multirow{2}{*}{$\begin{array}{c}\text { Cholesterol, } \\
\mathrm{mg} / 100 \mathrm{~g}\end{array}$} \\
\hline $18: 1 n 9$ & Saturated & Monounsaturated & Polyunsaturated & & \\
\hline $34.9 \pm 0.9$ & $37.2 \pm 0.6$ & $42.9 \pm 1.1$ & $20.0 \pm 1.5$ & $3.04 \pm 0.30$ & $30.7 \pm 1.4$ \\
\hline
\end{tabular}

The fat deposition in swine increases with the weight, either in backfat or intramuscular fat (Cisneros et al., 1996) and, as discussed, intramuscular fat content is inversally proportional to unsaturated fat. So, the slaughter of heavier animals could result in modification of fatty acid profile because total lipids content on loin numerically increased with the higher slaughter weight, except for the animals submitted to $20 \%$ qualitative restriction diets. In contrast to water holding capacity, the highest content of lipid observed on heavy swine contributes positively with the juiciness (Warriss, 1995) and tenderness (Fernandes et al., 1999) traits.

\section{Morpho-histochemical characteristics}

Results of fiber tipification are showed at Table 6 and Figure 1. Strong reaction for nadh-tr method (dark-gray color) indicated oxidative metabolism. Comparing nadh-tr and atp-ase slides it was observed that light and intermediate-gray fibers (glycolityc and oxidative-glycolityc metabolism) showed dark-blue color, strong reaction in atp-ase method and they were classified as FG and FOG fibers, respectively. Light-blue fibers in atp-ase method showed dark-gray color in nadh-tr method, indicating slow-twich and oxidative metabolism (SO) fiber.

Data related to frequency and area of cross sections of muscular type fibers of Multifidus muscle are presented in Table 7. Frequencies of fiber types were not significantly different $(\mathrm{P}>0.1)$. Quadratic effect $(\mathrm{P}=0.08)$ for area of SO fiber was achieved, obtaining the highest area value at $10.5 \%$ of qualitative restriction.

Although no significant $(\mathrm{P}>0.1)$ results were observed for the areas of the other fiber types, it was worth noting that the same standard of SO fiber values were obtained. Quadratic equations demonstrated that maximum values for $\mathrm{FG}$ and FOG fibers were $10.1 \%$ and $11.7 \%$, respectively. The mean value was $10.8 \%$, taking into account all three obtained results, number being very close to statistically significant data found for SO fibers.

Animals showed higher content of lean meat as consequence of qualitative feed restriction. The increase of muscular mass occurs mainly due to the process of fiber hypertrophy, or by increase of cellular area. According to the present results, the highest hypertrophy of Multifidus muscle was observed at a level of $11 \%$ of qualitative feed restriction. 
Table 6 - Fiber classification of Multifidus dorsi swine muscle according to results from different enzymatic methods.

\begin{tabular}{lcc}
\hline \multirow{2}{*}{ Classification } & \multicolumn{2}{c}{ Method } \\
\cline { 2 - 3 } & ATP-ase & NADH-TR \\
\hline Slow-twitch / oxidative metabolism (SO) & light-blue & dark-gray \\
Fast-twitch / glycolityc metabolism (FG) & dark-blue & light-gray \\
Fast-twitch / intermediate metabolism (FOG) & dark-blue & intermediate-gray \\
\hline
\end{tabular}
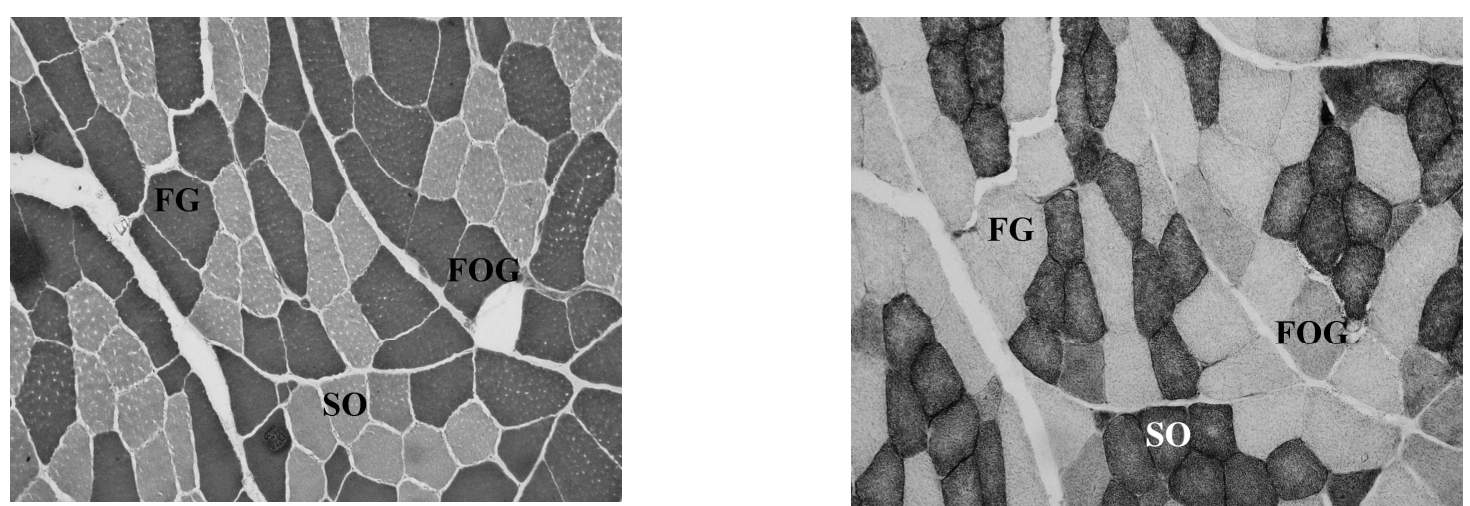

Figure 1 - Cross slices of Multifidus dorsi swine muscle. SO = slow-twitch and oxidative metabolism fiber; FG = fast-twitch and glycolityc metabolism fiber; FOG = fasttwitch and intermediate metabolism fiber. On the left, ATP-ase reaction (Fast-twitch fiber in dark-blue). On the right, NADH-TR reaction (oxidative metabolism fiber in dark-gray). Magnification $20 x$.

Table 7 - Effect of qualitative feed restriction on frequency and area of Multifidus dorsi muscle fibers of heavy swine.

\begin{tabular}{|c|c|c|c|c|c|c|}
\hline \multirow{2}{*}{ Trait $^{(1)}$} & \multicolumn{5}{|c|}{ Qualitative feed restriction, \% } & \multirow{2}{*}{$\mathbf{P}$} \\
\hline & $0(n=8)$ & $5(n=6)$ & $10(n=9)$ & $15(n=9)$ & $20(n=9)$ & \\
\hline \multicolumn{7}{|c|}{ Fiber frequency, $\%$} \\
\hline $\mathrm{SO}^{(2)}$ & $27.4 \pm 2.6$ & $31.6 \pm 3.0$ & $21.2 \pm 2.2$ & $21.5 \pm 2.2$ & $30.9 \pm 2.4$ & NS \\
\hline FG & $59.0 \pm 2.3$ & $54.9 \pm 2.7$ & $52.6 \pm 2.0$ & $55.3 \pm 2.0$ & $53.7 \pm 2.1$ & NS \\
\hline FOG & $13.6 \pm 2.1$ & $13.5 \pm 2.5$ & $16.2 \pm 1.9$ & $13.2 \pm 1.8$ & $15.5 \pm 1.9$ & NS \\
\hline \multicolumn{7}{|c|}{ Fiber area. $\mu \mathrm{m}^{2}$} \\
\hline SO & $4467 \pm 418$ & $6081 \pm 491$ & $4831 \pm 367$ & $5638 \pm 359$ & $4880 \pm 385$ & $\mathrm{Q}(0.08)$ \\
\hline FG & $8117 \pm 608$ & $8978 \pm 715$ & $8511 \pm 534$ & $9468 \pm 523$ & $7912 \pm 561$ & NS \\
\hline FOG & $4641 \pm 352$ & $4955 \pm 460$ & $4917 \pm 306$ & $5435 \pm 349$ & $4704 \pm 323$ & NS \\
\hline
\end{tabular}

${ }^{1}$ SO - slow-twitch and oxidative metabolism fiber. FG - fast-twitch and glycolityc metabolism fiber. FOG - fast-twitch and oxidative-glycolityc metabolism fiber.

${ }^{2}$ SO fiber area $=4718.7+161.4 \mathrm{x}-7.7 \mathrm{x}^{2}\left(\mathrm{R}^{2}=30.5\right)$. 
Assuming that all fibers responded in a similar pattern to diets, qualitative feed restriction did not determine the differential development of SO, FG or FOG fibers, not even modification on frequencies of type fibers occurred. According to Lefaucher and Gerrard (1998), energetic restrictions increase the muscle fiber areas, but does not alter proportion among the cellular types, at least during the growth and finishing phases of pigs. Gondret et al. (2000) did not observe effect of feed restriction for finishing rabbits on muscle fiber areas, but authors reported a proportional reduction of oxidative fibers in Longissimus muscle. No response on the others tested muscles of restricted animals, biceps femoris and semimembranosus were recorded. Thus, responses among muscles to nutritional inducement appear variable. Besides, maximum level of restriction used here was $20 \%$ that was lower than plane of restriction causing some cellular modulations on other sorts of studied animals. Thus, intensity of feed restriction together with divergent results observed among different muscles could justify the lack of response on the frequency of type fibers.

Table 8 shows values related to each fiber type of swine $M$. dorsi muscle. FG was the most abundant fiber type observed. However, its frequency was lower than observed on Longissimus and on light part of Semitendinosus by Bee (2004). Frequency of SO fibers was higher than FOGs' in the present trial, but it was not observed by Bee (2004), even on the dark portion of Semitendinosus. The profile of fibers observed in the $M$. dorsi was closer than red meats, with proportionally higher frequency of oxidative fibers. Local stabilization muscles showed this profile, in contrast to global mobilization muscles, such as Longissimus ones (Schilling, 2005).

Table 8 - Mean values of frequency and cross section area of fiber types on Multifidus dorsi muscle of heavy swine

\begin{tabular}{|c|c|c|}
\hline \multirow{2}{*}{ Fiber type } & \multicolumn{2}{|c|}{ Characteristic } \\
\hline & Frequency, \% & Area, $\mu \mathrm{m}^{2}$ \\
\hline $\mathrm{SO}^{(1)}$ & 30.6 & 5106 \\
\hline FG & 55.0 & 8546 \\
\hline FOG & 14.4 & 4901 \\
\hline
\end{tabular}

${ }^{1}$ SO - slow-twitch and oxidative metabolism fiber. FG - fast-twitch and glycolityc metabolism fiber. FOG - fast-twitch and oxidative-glycolityc metabolism fiber.

Cross sectional area of FG was higher than the other fiber types. Generally, fibers of mixed metabolism (FOG) have intermediated size, considering those smaller SOs' and higher FGs' fibers (Picard et al., 2002), which was not consistent with results of the present study. Moreover, Bee (2004) observed variations among muscles on proportional size of fibers, being area of intermediate fibers closer to SOs' and FGs' as well. According to Schilling (2005), the difference among the fiber size reduced according the depth of the muscle.

FOG frequency on $M$. dorsi was positively (0.37; $\mathrm{P}<0.05)$ and negatively $(-0.34 ; \mathrm{P}<0.05)$ correlated with $\mathrm{a}^{*}$ value, indicative of meat redness, and with total lipid concentration of $L$. lumborum, respectively. Otherwise, FG (-0.35) and FOG (0.32 ) fiber areas showed inverse correlations $(\mathrm{P}<0.05)$, respectively, with cholesterol content and water holding capacity. Morpho-histochemical characteristics of muscles have been related to pork meat quality (Bowker et al., 2000; Picard et al., 2002), mainly regarding to meat susceptibility to PSE condition But, although the relations envolved different muscles, correlations here observed were higher than those values described by Klosowska and Fiedler (2003), ranging from 0.10 to 0.21 for Longissimus muscle.

Klont et al. (1998) reported negative and positive relationships of glicolytic fibers with water holding capacity and intramuscular fat content, in partial agreement with observed correlations of this study. FOG showed intermediate characteristics as related to SO fibers, red and dependent on lipid supply, and FG, white and with glicolytic store (Picard et al., 2002).

However, relations among different muscles have some signification if variations on the characteristics of Multifidus are also observed for Longissimus. Morphochemical characteristics of muscles depend on their localizations and their functions (Lefaucheur and Gerrard, 1998). 
Multifidus and Longissimus muscles are adjacent at lumbar region, being the first located closer to vertebral column and functioning exclusively on its sustainability, while the second is responsible for lateral, extension and flexion movements of the column (Jones et al., 2006), contributing to differences among these muscles. On the other hand, FG and FOG distribution around $\mathrm{SO}$ as shown in Figure 1, could be worth to notice, forming cluster arrangements as observed by Fonseca et al. (2003) for swine Longissimus.

\section{ACKNOWLEDGEMENTS}

Research supported by FAPESP - first author fellowship. Authors would like to thank at teamwork of Laboratories: Pathological Clinic, Histology, Technology on Animal Products, and Plant Microorganism Biochemical, FCAV/UNESP - Campus of Jaboticabal.

\section{RESUMO}

Para avaliar o efeito de diferentes níveis de restrição alimentar qualitative $(0,5,10,15$ e $20 \%)$ sobre a qualidade da carne e características morfohistoquímicas musculares, sessenta suínos machos castrados foram utilizados. Dez suínos formaram o grupo abatido inicialmente ( $89 \mathrm{~kg} \mathrm{PV})$ e outros 50 suínos foram alimentados com as dietas experimentais e foram abatidos aos $128 \mathrm{~kg} \mathrm{PV}$. A restrição qualitativa aumentou $\mathrm{o} \quad \mathrm{pH}_{45}$, e a capacidade de retenção de água, bem como reduziu a coloração vermelha e amarela, e o teor de colesterol do músculo Longissimus lumborum. Tendência quadrática para conteúdo de ácido oléico do lombo e da área de seção transversal do músculo Multifidus dorsi $(\mathrm{P}=0.08)$ foram observada, com ponto de máxima em11-12\% de restrição. Não foi encontrado efeito $(\mathrm{P}>0.1)$ na porcentagem de fibras SO, FG e FOG no músculo Multifidus. A carne dos animais abatidos aos 128 $\mathrm{kg}$ PV apresentou valores numericamente maiores para coloração, perda de água e conteúdo lipídico, bem como menor força de cisalhamento que a dos animais abatidos aos $89 \mathrm{~kg} \quad \mathrm{PV}$. Restrição alimentar qualitativa para suínos em terminação não afeta negativamente a qualidade da carne nem altera o padrão de fibras musculares.

\section{REFERENCES}

Affentranger, P.; Gerwig, C.; Seeewer, G. J. F.; Schwörer, D. and Künzi, N. (1996), Growth and carcass characteristics as well as meta and fat quality of three types of pigs Ander different feeding regimens. Livestock Production Science, 45, 187-196.

Akiba, Y.; Sato, K. and Takahashi, K. (2001), Meat color modification in broiler chickens by yeast Phaffia rhodozyma containing high concentrations of astaxanthin. Journal of Applied Poultry Research, 10, 154-161.

Bee, G. (2004), Effect of early gestation feeding, birth weight, and gender of progeny on muscle fiber characteristics of pigs at slaughter. Journal of Animal Science, 82, 826-836.

Bligh, E. G. and Dyer, W. J. (1959), A rapid method of total lipid extraction and purification. Canadian Journal of Biochemistry Physiology, 37, 911-917.

Bowker, B. C.; Grant, A. L.; Forrest, J. C. and Gerrard, D. E. (2000), Muscle metabolism and PSE pork. In: ANNUAL MEETING OF AMERICAN SOCIETY OF ANIMAL SCIENCE, 2000. Electronic annals... Available in: <http://www.asas.org/symposia/0601. pdf>. Access: 03 Jul, 2005.

Bragnolo, N. and Rodriguez-Amaya, D. B. (2002), Teores de colesterol, lipídeos totais e ácidos graxos em cortes de carne suína. Ciência e Tecnologia de Alimentos, 22, 98-104.

Brewer, M. S.; Zhu, L. G. and McKeith, F. K. (2001), Marbling effects oon quality characteristics of pork loin chops: consumer purchase intent, visual and sensory characteristics. Meat Science, 59, 153-163.

Cameron, N. D.; Enser, M.; Nute, G. R.; Whittington, F. M.; Penman, J. D.; Fisken, A. C.; Perry, A. M. and Wood, J. D. (2000), Genotype with nutrition interaction on fatty acid composition of intramuscular fat and the relationship with flavour of pig meat. Meat Science, 55, 187-195.

Cisneros, F.; Ellis, M.; McKeith, F. K.; McCaw, J. and Fernando, R. L. (1996), Influence of slaughter weight on growth and carcass characteristics, commercial cutting and curing yields, and meat quality of barrows and gilts from two genotypes. Journal of Animal Science, 74, 925-933.

Corte, O. O., Felício, P. E. and Cia, G. (1979), Sistematização da avaliação final de bovinos $e$ bubalinos. III. Qualidade da carne. ITAL, Campinas, Boletim Técnico do CTC n.3, 66-76.

Delaney, B; Nicolosi, R. J.; Wilson, T. A.; Carlson, T.; Frazer, S.; Zeng, G-H; Hess, R.; Orstergren, K.; Haworth, J. and Knutson, N. (2003), $\beta$-Glucan fractions from barley and oats are similarly antiatherogenic in hypercholesterolemic syrian golden hamsters. Journal of Nutrition, 133, 468-495. 
Dubowitz, V. and Brooke, M. (1973), Muscle biopsy: a modern approach. Sunders, London.

Ellis, M.; Webb, A. J.; Avery, P. J. and Brwon, I. (1996), The influence of terminal sire genotype, sex, slaughter weight, feeding regime and slaughter-house on growth performance and carcass and meat quality in pigs and on the organoleptic properties of fresh pork. Animal Science, 62, 521-530.

EMBRAPA. Centro Nacional de Pesquisa de Suínos e Aves. (1991), Tabela de Composição Química e Valores Energéticos de Alimentos para Suínos e Aves. Embrapa-Cnpsa, Concórdia. (Documentos, 19).

Ennion, S.; Pereira, J. S. A.; Sargeant, A. J.; Young, A. and Golspink, G. (1995), Characterization of human skeletal muscle fibers according to the myosin heavy chains they express. Journal of Muscle Research and Cellular Motility, 16, 35-43.

Fernandez, X.; Monin, G.; Talmant, A.; Mourot, J. and Lebret, B. (1999), Influence of intramuscular fat content on the quality of pig meat. 1.Composition of the lipid fraction and sensory characteristics of $\mathrm{m}$. longissimus lumborum. Meat Science, 53, 59-65.

Fonseca, S.; Wilson, I. J.; HOrgan, G. W. and Maltin, C. A. (2003), Slow fiber cluster pattern in pig longissimus thoracic muscle: Implications for myogenesis. Journal of Animal Science, 81, 973-983.

Garnier, J. P., Klont, R. and Plastow, G. (2003), The potential impact of the current animal research on the meat industry and consumer attitudes towards meat. Meat Science, 63, 79-88.

Garrido, M. D.; Pedauyé, J.; Bañón, S. and Laencina, J. (1994), Objective assessment of pork quality. Meat Science, 37, 411-420.

Gondret, F.; Lebas, F. and Bonneau, M. (2000), Restricted feed intake during fattening reduces intramuscular lipid deposition without modifying muscle fiber characteristics in rabbits. Journal of Nutrition, 130, 228-233.

Guárdia, M. D., Estany, J.; Balash, S.; Oliver, M. A.; Gispert, M. and Diestre, A. (2004), Risk assessment of PSE condition due to pre-slaughter conditions and RYR-1 gene in pigs. Meat Science, 67, 471-478.

Guth, L. and Samaha, F. J. (1970), Procedure for the histochemical demonstration of actomyosin ATPase. Experimental Neurology, 28, 365-367.

Hamm, R. (1986), Functional properties of the myofibrilar system and their measurements. In: P.J.Betchel, Muscle as Food. 3.ed., Academic Press, Orlando, 135-199.

Jones, S. J.; Guru, A.; Sing, V. and Jones, T. F. (2006), Porcine myology. Available in <http://porcine.unl.edu>. Access: 04 Sep, 2007.

Kay, R. McP. (1982), Dietary fiber. Journal o. Lipid Research, 23, 221-242.
Klont, R. E.; Brocks, L. and Eikelenboom, G. (1998), Muscle fiber type and meat quality. Meat Science, 49, S219-S229.

Klosowska, D. and Fiedler, I. (2003), Muscle fiber types in pigs of different genotypes in relation to meat quality. Animal Science Papers and Reports, 21, S49-S60.

Latorre, M. A.; Lázaro, R.; Valencia, D. G.; Medel, P. and Mateos, G. G. (2004), The effects of gender and slaughter weight on the growth performance, carcass traits, and meat quality characteristics of heavy pigs. Journal of Animal Science, 82, 526-533.

Lefaucheur, L. and Gerrard, D. (1998). Muscle fiber plasticity in farm mammals. In: ANNUAL MEETING OF AMERICAN SOCIETY OF ANIMAL SCIENCE, 1998. Eletronic annals... Available in <http://www.asas.org/JASsymposia/ proceedings/0307.pdf>. Access: 28 Jun, 2005.

NRC. National Research Council (1998), Nutrient requirement of swine, 10.ed. National Academic Press, Washington.

Ogilvie, R. W. and Feeback, D. L. (1990), A metachromatic dye-ATPase method for the simultaneous identification of skeletal muscle fiber types I, IIA, IIB and IIC. Stain Technology, 65, 231241.

Peter, J. B.; Bainard, R. J.; Edgerton, V. R.; Gillespie, C. A. and Stempel, K. E. (1972), Metabolic profiles of three fiber types of skeletal muscle in guinea pigs and rabbits. Biochemistry, 11, 2627-2633.

Pettigrew, J. E. and Esnaola, M. A. (2001), Swine nutrition and pork quality: a review. Journal of Animal Science, 79, E316-E342.

Picard, B.; Lefaucher, L.; Berri, C. and Duclos, M. J. (2002), Muscle fiber ontogenesis in farm animal species. Reproduction Nutrition Development, 42, 415-431.

Ramonet, Y.; Meunier-Salaün, M. C. and Doumand, J. Y. (1999), High-fiber diets in pregnant sows: digestive utilization and effects on the behavior of the animals. Journal of Animal Science, 77, 591-599.

Rostagno, H. S.; Albino, L. F. T.; Donzele, J. L.; Gomes, P. C.; Ferreira, A. S.; Oliveira, R. F. and Lopes, D. C. (2000), Tabelas brasileiras para aves $e$ suínos - composição de alimentos e exigências nutricionais. Imprensa Universitária/UFV, Viçosa.

Sainz, R. D. and Araújo, F. R. C. (2001), Tipificação de carcaças de bovinos e suínos. Papaer presented at $1^{\text {st }}$ Congresso Brasileiro de Ciência e Tecnologia de carne, 22-25 October, São Pedro, São Paulo.

SAS. Statistical analyses system (1998), SAS user's guide: statistic - version 6.12.ed, SAS Institute, Carry. 
Schilling, N. (2005), Characteristics of paravertebral muscles - fiber type distribution pattern in the pika, Ochotona rufescens (Mammalia:lagomorpha), JZS, 43, 38-48.

Shimokomaki, M. (2003), Princípios da qualidade da carne. Paper presente at $1^{\text {st }}$ Simpósio de Qualidade de Carne, Jaboticabal, São Paulo.

Souza, V., L., F. and Silva, R. S. S. F. (2006), Dietary vitamin $\mathrm{E}$ supplementation on cholesterol and cholesterol oxides of pig meat and cooked ham. Braz. arch. biol. technol., 49, 197-205.
Warriss, P. (1995), Considerations on methods of assessing pork meat quality. Paper presented at $1^{\text {st }}$ Conferência Internacional Sobre Ciência e Tecnologia de Produção de Suínos, 21-26 April, Campinas, São Paulo.
Received: February 12, 2007; Revised: September 27, 2007; Accepted: December 22, 2008. 